Georgetown University Law Center

Scholarship @ GEORGETOWN LAW

2019

\title{
On Being Old Codgers: A Conversation about a Half Century in Legal Education
}

Mark Tushnet

Harvard Law School, mtushnet@law.harvard.edu

Louis Michael Seidman

Georgetown University Law Center, seidman@law.georgetown.edu

This paper can be downloaded free of charge from:

https://scholarship.law.georgetown.edu/facpub/2157

https://ssrn.com/abstract=3370965

This open-access article is brought to you by the Georgetown Law Library. Posted with permission of the author. Follow this and additional works at: https://scholarship.law.georgetown.edu/facpub

Part of the Constitutional Law Commons, Legal Education Commons, and the Legal History Commons 


\title{
On Being Old Codgers:
}

\section{A Conversation about a Half Century in Legal Education}

\author{
Mark V. Tushnet* \\ Louis Michael Seidman**
}

The conversation that follows, conducted over three evenings, captures some of our thoughts about the last half century of legal education as both of us near retirement. We have edited the conversations so as to eliminate verbal stumbles and present our ideas more coherently, slightly reorganized a small part of the conversation, and added a few explanatory footnotes. However, we have attempted to keep the informal tone of our discussions.

I.

Seidman: The two of us have been consumers of and producers of legal education for more than a half century and so it seemed to us that it might be worthwhile in our final years of doing this to think some about how things were when we started, how things are now, whether things are better or worse, and where things might be going in the future. ${ }^{1}$

We thought we would start by discussing the student experience. Mark, it seems to me maybe the most obvious difference in the student experience is that when we started, law schools were entirely white or almost entirely white and almost entirely male. There were a handful of women students, a handful of students of color, essentially no women faculty, and no faculty of color. Today in most law schools nearly half the student body is women and a substantial portion of the student body is people of color, so things have changed pretty dramatically.

* William Nelson Cromwell Professor of Law, Harvard Law School.

** Carmack Waterhouse Professor of Constitutional Law, Georgetown

University Law Center. We are grateful to Mary Ann Derosa for transcribing this conversation.

1 We met and became good friends while clerking for Justice Thurgood Marshall during the 1971 Term. Tushnet began his teaching career at The University of Wisconsin Law School in 1973, moved to the Georgetown University Law Center in 1981, and has taught at Harvard Law School since 2006. He has visited at the University of Texas Law School, University of Southern California Law School, New York University Law School, Columbia Law School, and the University of Chicago Law School. Seidman has taught at the Georgetown University Law Center since 1976. He has visited at The University of Chicago Law School, Harvard Law School, New York University Law School, and the University of Virginia Law School. 
Tushnet: I think that's right. It's worth observing with respect to the issue of gender that we started law school, I in 1967, you in '68, just as the draft deferments for men were expiring, and so law schools, anticipating a drop in the male enrollment, actually expanded female enrollment to fill the seats and to get the tuition. So we were there as students just at the beginning of the large infusion of women into law school classes.

Now it took a long time to reach rough parity. I think it's been maybe for the past ten years or so most law schools have been hovering around 45 to 50 percent women enrollment, but the growth in numbers started shortly after we began as law students. I agree that it has to have changed the experience of students, although when you talk about experience at the level of what the classroom feels like it's hard for me to go back and think about what it felt like in 1967-68, and it's very hard for me to figure out what it feels like to the students I'm teaching today. I can't project myself into it very well and for I think probably personally idiosyncratic reasons, I distanced myself from that classroom experience at Yale as a student. So I'm not sure I have any good sense of what other people were experiencing.

Seidman: That's interesting along a number of dimensions. First, I think you're right that around the time we were in law school the number of women was really expanding, but perhaps paradoxically at that time gender wasn't really something talked about in the classroom. That's in part because of where the law was. It was the other way around with race. Expansion of minority enrollment, to the extent that there was one, came mostly a little later. But race was a hot topic in the classroom. Unfortunately, it was a topic that was talked about by white people who were talking about people of color - not a really very healthy environment.

If you think about today, the change in the gender composition of law schools has actually made quite a large if subtle difference. Law schools today are much less classically male than they were then. At that time, the classroom experience was very adversarial. I'm not saying that's gone away completely, but the Socratic method was a kind of contact sport and one that at least on certain versions of feminism is male.

Today law schools tend to be much more collaborative and less hardedged. I think that is at least partially because of the change in gender composition and gender dynamics. ${ }^{2}$ Oddly with regard to race there is much less difference. When race is the subject, I still have the sensation of white

2 There may well be strong pedagogical reasons for the change. Law practice is often collaborative, and legal training appropriately reflects that fact. 
people talking about people of color. ${ }^{3}$ Law schools still feel like very white institutions. The difference probably relates to critical mass. As you say, law schools are trending toward being close to half women. The minority enrollment, at least the African American and Hispanic enrollment, is much smaller today, although greater than it was when we were there. And there are certainly minority faculty, whereas there used to be none.

Tushnet: I just wanted to note a couple of things on the gender issue. When I was in law school, I believe in my second or third year, a group of mostly female students organized what I think was Yale's first Women in the Law class and sort of petitioned the faculty for its recognition as a class. The way it was organized was that each student in the class found an individual faculty member to supervise a research paper on women in the law. There may have been a short course the year before that provoked this response, but that was the first formal appearance of gender as a discrete topic at Yale.

On where things are now, there have been a whole bunch of things that contribute to the softening of the hard edges of the Socratic method. In my classes over the past several years I've done a writing exercise in which I ask each student to evaluate another student's paper and I then read a subset of the papers with the comments on them. My reaction routinely has been that they were too gentle with each other in their critical observations. That supports the idea that the sort of adversariness ...

Seidman: Of course you said that, you're a man

Tushnet: Right, no, no...

Seidman: That would be a man's perspective which, perhaps demonstrates that, for better or worse, things have changed. Another thing that has changed is that when we were in law school there were just blatant and really inexcusable attacks on women, belittling of women, a sense that women didn't belong there, ridiculing of women. That has disappeared or mostly disappeared. I'm not saying there aren't more subtle forms of gender discrimination. Law schools remain to some degree male institutions but some of the overt forms of sexism and misogyny are gone.

Tushnet: I think that may be overstated. There still are noticeable incidents -- not pervasive -- but incidents of sort of graffiti-like things, anonymous postings on the walls that are sexist in the classical sense.

Seidman: And one has to acknowledge the \#MeToo movement has revealed a fair number of abuses by faculty and students that still go on.

3 Obviously, we are talking about our experience as teachers who are white. It is possible that the classroom experience is very different when the teacher is a person of color. However, Tushnet notes that in his accreditation visits, he has not noticed dramatic differences based on the professor's race. 
You mentioned a moment ago the draft, and in terms of student experience, that's another very big difference that it's hard for people who weren't alive then to completely understand.

In part because the students were overwhelmingly male, there was a pervasive sense of fear and anxiety about the draft and about the War that overhung everything. It was very hard to concentrate completely on law school when you were worried about being drafted and possibly being killed. There is really nothing like that today. There is a fair amount of dread about the future in terms of things like global warming and so on, but there is not that immediate sense of fear and danger.

Generalizing from that, the politics then were much more immediate then than they are now, much more palpable. That sense inevitably invaded the classroom, so law schools, my law school and your law school, were shut down for periods of time because of political unrest. It's hard to imagine something like that happening today.

Tushnet: Well again a couple of years ago at Harvard there was a building occupation by the black law students which generated a great deal of turmoil and some degree of change, and responsiveness by the institution, so yes and no. And it's probably worth observing here what we're recounting is our experience at Harvard and Yale, elite institutions. Our teaching experiences have been primarily in elite or elite adjacent institutions, Georgetown, Wisconsin, for me now Harvard. The experience of students in other institutions might be quite different.

Seidman: That's an important point and I want to get back at some point to talking about the divide between so called elite or not elite institutions.

What do you think differences are in terms of student experience regarding jobs and professional education as preparation for jobs?

Tushnet: I think here we really have to recount the history of the legal profession in the late $20^{\text {th }}$ and early $21^{\text {st }}$ centuries because that's what students were responding to. In the late $20^{\text {th }}$ century there was a boom in the legal market all across the country, one indication of which is that enrollments in law schools went up. Law schools were created to satisfy demand for seats that would lead to jobs. What's now known as BigLaw came into existence, multihundred member law firms that had offices in big cities around the country and the world. That's a phenomenon that actually didn't exist when we were in law school. My version of this is that Jones Day, which is now one of the largest law firms in the world, was a Cleveland law firm when we were in law school.

So you have this booming market and then a collapse in 2008. The market just plummeted, and the effect of that was to substantially reduce the number of jobs available, and to generate a great deal of anxiety of different sorts depending on where in the hierarchy you were. At Harvard the anxiety 
was you might not be able to get a job in Boston, Washington or New York. You would have to look for a job in Indianapolis, but at least you could get one in Indianapolis. You would have to look longer and so on. At other institutions, students couldn't get a job at a big law firm, but you would end up getting a job in a much smaller law firm or some other institution. Jobs that required a law degree disappeared and some people were taking jobs where they didn't need a law degree.

Over the past four or five years the market has rebounded and at least at Harvard the anxieties, which weren't all that great even during the collapse period, have basically disappeared. People went back to where they were before 2008 in terms of thinking about jobs in the future.

Seidman: It's interesting that maybe the total level of anxiety remained about the same then and now, but the anxiety has different sources. In 1968, many people were worried about the draft and 50 years later they are worried about getting jobs.

By my lights, the modern worry has had a really deleterious effect on legal education. Law schools have always had a complicated and fraught relationship with the profession. There is inevitable tension because law schools are part of universities, but they are training people for the profession. Because law schools are a part of universities, what they do is not necessarily in the best interests of the narrow professional concerns that people who run law firms have.

The absence of jobs has changed the balance of power between law firms and law schools. Law schools are now more concerned about what it is that lawyers want students to learn, about the kind of training that is useful to law firms. That has eroded the sense of law schools as parts of universities that have the values that universities hold.

Now this gets back to the hierarchy. This effect has been unevenly distributed. For the law schools at the very top of the hierarchy there has been much less change. Towards the bottom it's been much more severe. But I think that all law schools are the worse for it.

Tushnet: There are a number of other elements in this transformation which, I agree, has occurred again differentially depending on where you are in the hierarchy. I would make two points, one from the profession's side and one from the law school side. From the side of the profession, really starting before the collapse in 2008 but accentuated by that collapse, the business model of law firms changed partly in response to the demands from their clients. In the boom years, large law firms would hire young people who had been certified as smart and ambitious by going through law school and then provide them with firm-specific education, education for the stuff the firm was actually doing. Clients started saying why should we pay to educate these young lawyers? So law firms gradually changed their model to say okay we're 
going to hire young lawyers who will be more or less practice ready when they arrive.

Seidman: And just to interrupt for a second, that was aggravated by the emergence of free agency. It doesn't make sense to invest a lot of money in training somebody if they are going to go to another law firm in a couple of years. The sense that people stayed in one law firm over a career has really eroded. That also means that law firms want law schools to do this work for them.

Tushnet: Right. I think you and I have somewhat different views about this, but one effect of this transfer of the educational function back to the law schools has been a proliferation of what is now labeled experiential education, which is the modernized version of clinical legal education with a twist. In its origins clinical legal education was a mechanism of training young lawyers by having them provide services to people who couldn't afford to buy services from already certified lawyers. It's not the greatest way to do things in the abstract, but people who wouldn't have access to legal services got some access through not fully trained lawyers who were being sort of supervised by full-scale lawyers.

The current version of experiential education retains some dimensions of the prior clinical experience and service to the under-served, but because the demand from the profession for professional training is substantially greater than the amount of experiential education law schools provide, faculties are struggling to figure out what to do. In that struggle, the older form of clinical education has become only one part of the program.

Seidman: I see a much sharper distinction than you do between clinical education, which was just beginning to emerge when we were in law school, and what is now called experiential education or, often, externships. When it's done right, and I think it mostly is done right at least in elite institutions, clinical education really is an academic exercise. The model is students go out in the world. They engage in actual practice and then they come back to the classroom where they theorize about the practice they are engaged in and think critically about it. They do the kinds of analysis that academic institutions are good at because they are somewhat removed from the actual practice. It was a point of pride when I arrived at Georgetown that every clinic was supervised by a faculty member who was engaged in the academic exercise that law schools are at least in part devoted to.

Now I don't want to overstate this. We had a range of faculty members who were more or less academically inclined. But that was the model, and the academic component of it was really important. What's happened now is that there are still clinics, but they are beginning to lose out. What's going on now is something that is quite different. We are just farming out students in large numbers to people who are practicing law. There is very little reflection about 
what's going on. Students are learning narrow practical skills which are often not transferable and therefore not things that are going to serve them well throughout a career when they are in a different place -- where there are different judges and different local practices. More importantly, there is not any kind of critical element to this kind of education. I don't want to overstate it, but it is a kind of tragedy. There has been a diminution of law schools and of the unique function that they've historically served at the intersection of practice and theory. The old model was students were engaged the preparation for practice but also theorizing about what they were doing.

Tushnet: It's worth noting I think that some of these concerns are concentrated in the elite schools and that at schools lower in the hierarchy the kind of externship practice and the like can be quite valuable for the students. The question is what does it replace, and your concern I think is that at the elite schools, it replaces the kind of theoretical reflection that you think is distinctive of law as an academic enterprise. It's less clear to me that it replaces that at the less elite schools, and so it might be that this kind of expansion of experiential education is net a benefit in the universe of legal education as a whole.

I do want to say one thing about law schools as academic enterprises. One of the things that happened during the boom years was that the academic ambition of law schools spread almost pervasively throughout the hierarchy. (I can think of only one law school that in the late $20^{\text {th }}$ century self-consciously resisted that transformation). You could see this in their hiring practices. The hiring of people with advanced degrees in disciplines other than the law spread throughout the hierarchy. Although, of course, more concentrated in the elite schools.

Now, the collapse has placed a lot of pressure on those institutions partly because the faculties can't change that quickly. The J.D./ Ph.Ds. at institutions in the mid-range are nearing retirement and I don't really know what's going to happen, particularly given the recovery in the legal market, to those institutions in the future.

Seidman: That all seems right to me. But I reject the idea that only students at elite institutions would benefit from this tension -- the unique tension - stemming from the fact that law schools are situated between practice and theory, between academic institutions and the real world. That is what makes law schools on the one hand different from philosophy departments and on the other hand different from vocational training. It is a unique and important role. As you say, the boom years demonstrated that nonelite institutions could serve their students in that way also.

Tushnet: Given different institutions, it might be appropriate for there to be different distributions of interest or different kinds of orientation among the faculty. When I was teaching at Wisconsin, which was what I called earlier 
an elite adjacent institution, then and I think probably still now, there were lots of people interested in social science and the law, lots of people interested in the critical perspective on the law. But there was also a course in general practice that was terrifically well designed. It was for students who were going back to their home towns and opening up solo practice in rural Wisconsin. It was a great thing for the law school to have. It wouldn't be great if that was the only thing in the law school.

Seidman: Or if that was the only course that law students took.

Tushnet: Right, right. But it got a lot of credits. My image is of law schools with a range of institutional commitments, some highly academically oriented, others primarily oriented to producing lawyers who will provide services to mostly middle class clients and within each of those institutions a distribution of faculty members with varying orientations. I agree that every law school should be in a position to offer some degree of what I think you are calling a critical perspective on the institutions of law and the practice of law. I think we may disagree about the extent to which every institution should have roughly similar distribution internally.

Seidman: The area where we certainly agree is that law schools straddle this line between practice and theory and that inevitably there is going to be a tension between those two and the tension is a productive one. The question that you raise, and that I haven't thought hard enough about, is whether that tension has to exist in every law school class or if it's enough that some of the classes are oriented toward practice and some are oriented toward theory. Or even whether the tension has to exist in every institution, or if it's enough that some institutions are more theoretical and some are more practically oriented.

I want to make a broader point that is related to this discussion. When we were in law school, people took the enterprise much more seriously. They had much more self confidence that they were doing something of value.

Tushnet: At Harvard and Yale, that's where we were.

Seidman: That is where we were that's true, but I think it's true more generally. People thought that law was serious. They thought that teaching law was valuable and important. They were giving something to students that students needed and wanted, and they were serious about the enterprise.

Here are some examples of how that sense has eroded. When I started at Georgetown, we had two 15-week semesters. Over the time I've been there, that has shrunk so we now have two 13-week semesters. That means that over their three year career at Georgetown, students are getting three months less of legal education than they got 45 years ago. So far as I can see, that's led to no decline in the tuition that they are paying. You would think if they are getting three months less of legal education would entitle them to a substantial reduction in tuition. The reason they don't get it is because students are 
delighted to pay so they don't have to sit in classrooms with us and we're delighted to have them not sit in classrooms with us because we don't think we're giving them anything that is all that valuable.

Another example, which we've just been talking about, is externships where, again, students are paying the same amount of money for less contact with the faculty. We've essentially outsourced their education -- if they are indeed getting any education at all -- to people who have nothing to do with the law school. We are teaching them less for the same amount of money and everybody thinks this is just fine because the students don't want to be taught by us anyway. They don't think they are getting much of value from us, and we don't insist that we teach them because we don't think we're giving them much of value.

Tushnet: I want to interject two things. The first is that one of the most powerful lines for me in the literature of critical legal studies is in Roberto Unger's article-book called The Critical Legal Studies Movement which was published in 1983, a long time ago. And the line is that when we, the critical legal studies people, arrived in the legal academy our colleagues were like priests who had lost their faith but kept their jobs. ${ }^{4}$ Even as of 1980, critical legal studies folks at least understood, I think accurately, that the prior faith in the seriousness of law as an enterprise, a discrete, distinct enterprise, had been substantially eroded. The second point is on the diminution of the classroom time. I think an economist's reaction would be, well maybe our productivity in class has gone up so that we are able to accomplish same critical

Seidman: I just think that's wrong.

Tushnet: I'm less sure of that.

Seidman: I think that's wrong. There is no reason to think law professors have gotten more efficient. On your first point, yes, that's exactly right. In part because of critical legal studies, there has been an erosion of faith that we are doing anything valuable and a demoralization that's gone with that.

Now you know to some extent whether we're doing something valuable or not actually turns on whether we are taking it seriously or not. So there is a dialectic relationship here between how people feel about what they're doing and whether it has value.

4 "When we came, they were like a priesthood that had lost their faith and kept their jobs. They stood in tedious embarrassment before cold altars." Roberto Managubeira Unger, The Critical Legal Studies Movement, 96 Harv. L. Rev. 561, 675 (1983). 
Another example that occurs to me and, I have to admit, this really is old codgerism: When I was on the Law Review, again at an elite institution, the expectation was that you would do Law Review work for 40 hours a week and that you would then do your class work, which maybe would take 20 or 30 hours a week, so you would be working 60 to 70 hours a week. For large parts of the year, we had a new assignment every three days or so to produce a 10 to 15-page paper called a "prelim" on an area of the law that might be the topic for a student note. There is nothing remotely like this now. And when students wrote notes they went through three or four drafts with endless editing and rewriting.

Today, the line is that we could save some trees if law reviews just published the masthead and didn't bother with the rest of it. The students don't do that kind of work; they are not interested in it. The law reviews are essentially for the purpose of putting stuff on your resume.

Another example: I remember during my first year of law school at the end of the year, students were really concerned about the exams, so all the first year professors in my section got together and talked to the students. To a person - I should say to a man -- they said, you know you may think these grades are arbitrary but they absolutely are not. There is a real difference between a $\mathrm{B}+$ and an $\mathrm{A}$ - and that difference matters.

It's hard to imagine that anyone believes that today. There is a very strong sense that all of this is arbitrary and nonsense and of course that might be right, in fact it probably is right. But when you have these priests who have lost faith, it really has an impact on the religion. I think it begins to make it very peculiar and makes everybody wonder what they are doing and whether it's worthwhile at all.

Tushnet: At some level I don't disagree with that but I would add that the remainder of the Unger line is one I won't get exactly right, "in the mind's opportunity we had the heart's revenge."5 Even after the loss of faith, Unger was asserting -- and I want to say we in critical legal studies were asserting -that there were opportunities for the mind in law as a distinct intellectual enterprise.

Seidman: The shame is that the deconstructive part of critical legal studies seems to have been victorious but the constructive part seems to not have been. So people lost faith, but there is not a reconstructive hope to replace it. Now, maybe there will be at least in isolated places . . .

Tushnet: This is sort of a point of personal privilege. You may be right. Although as Duncan Kennedy has been quoted as saying critical legal studies

$5 \quad$ "They stood in tedious embarrassment before cold altars. But we turned away from those alters and found the mind's opportunity in the heart's revenge." Id. 
is dead, dead, dead, it's actually transformed the general understanding in the legal academy about what law is in a way that legal realism hadn't fully accomplished. So it's dead, but it lives on zombie-like in people in the center of the legal academy. The point of personal privilege is that I think there are still opportunities for the mind in doing ...

Seidman: The key word is opportunities. The question is whether the opportunities are being realized and that is in some ways the most troubling part of critical legal studies: The part that has prevailed hasn't been the deep sense of optimism and hope, but the cynicism and sense that none of it matters, that we're not doing anything useful, that law schools are for processing people and sorting them so that law firms can hire them. We really need to recapture the reconstructive part of CLS.

I think this is related to the decline of the Socratic method. Even when we were in law school it didn't exist in a pure form. I don't remember professors teaching courses where they only asked questions. But it was used, it was a contact sport, and there are quite good reasons why it's used much less now than it was then. It could be brutal. It was a way for faculty members to exercise power over students. It could be humiliating and terrifying. I was personally terrified by it. But it was also an indication of a seriousness that doesn't exist now.

The kind of teaching that I think has become quite prevalent -- and frankly it drives me up a wall -- is this: The professor asks a question, student A says "blah, blah, blah" and the professor says "that's a really good point." Student B raises her hand and says "yeah but blah, blah, blah." The professor says "That's a really good point also. Boy do we have smart students here." Student C: "blah, blah, blah." "Wow, I hadn't thought of that, that's a great point." So the net result of that is people are reinforced in the ideas they already have. There is much less effort to challenge them.

Our role is not to change students' minds, but it is to get them to hold the ideas they have in the most sophisticated form that they can be held. That requires that when a student says something, the professor pushes hard on it to see what the problems are so that the student can refine what she is saying. My sense is that even in elite institutions that is going on much less than it used to.

Tushnet: I am reasonably sure that that is correct. I should say again because of my self-distancing from my own legal education at Yale, I have no real recollection of what the pedagogy was like or what they were trying to do in class. I have snippets of memory but my experience at Yale was that the faculty didn't really care about teaching anyway. And the contrast at Harvard now is that the faculty does care about teaching. What counts as good teaching is something of a mystery to me. A non-trivial amount is sort of what you describe. I've heard descriptions of classes by teachers who are regarded as 
extremely successful and as using the Socratic method in which the faculty member elicits a response from a student and then turns to another student and says what do you think about that. Now there is a question mark at the end of it so it's quasi-Socratic. But it's not drilling down. On the other hand, there is one very highly regarded faculty member who by description does do the aggressive challenging which students don't like initially but end up accepting.

I want to come back to student reaction in a moment. When you describe the Student A, Student B thing, my reaction was a good faculty member might start out with Student A, the "blah, blah, blah" and say "that's really interesting" and then Student B does "blah, blah, blah" and then the faculty reaction should be "well that is really interesting but don't you see the tension between that and what Student A said." Or you go back to Student A. And I just don't know how much of that kind of teaching occurs. I've done accreditation visits at a fair number of schools and in the classes I've sat in on, the best teaching is done by lecture. The faculty member has worked something out and presents it to students so that they can think about the difficulties with an occasional probing question. What passes as Socratic or quasi-Socratic doesn't involve drilling down. ${ }^{6}$

Duncan Kennedy wrote about the Socratic Method when he was a law student. ${ }^{7}$ He said that one of its effects was to reproduce in the classroom the dynamics of what we would now call the father dominated family. One of the consequences of that, he said, was that students got strongly invested in fantasizing about the lives of the faculty members who were teaching them.

I take my students out to dinner fairly regularly and I have been struck by the degree to which that same kind of investment still occurs even though the pedagogy has changed quite dramatically, which suggests it's not the pedagogy but maybe the structure of education or legal education that generates it.

Seidman: The hierarchy is not just about the Socratic method although the Socratic method certainly reinforced it. There is another Freudian point that I think is true. Carol Gilligan ${ }^{8}$ would have something to say about the

6 Tushnet notes that he did observe a superb wholly Socratic - and nonintimidating - class taught by Kenneth Bamberger at the University of California - Berkeley Law School.

${ }^{7}$ Duncan Kennedy, How the Law School Fails: A Polemic, 1 Yale Rev. of L. \& Social Action 71 (1971).

8 Carol Gilligan, In a Different Voice: Psychological Theory and Women's Development (1982). Gilligan studied differences in the moral sensibilities of boys and girls. Simplifying greatly, boys (personified as "Jake") tended to see clear cut answers to moral problems. Girls (personified as "Amy") tended to 
Socratic method. This gets back to the presence of many more women in the law school class. What the Socratic method does is strip away all the complexity of the problem. You are faced with this very stark choice between doing one thing or another. If somebody says well what about this third possibility, a professor engaged in classic Socratic dialogue would accuse the student of "sliding off the hypothetical." In Gilligan's terms, this is a very "Jake" way of thinking and not an "Amy" way of thinking at all. It is conflictual, it is black and white, it is aggressive and it is male.

Tushnet: I also want to say that it's also bad jurisprudentially because the proper response to the other possibility is not, "You are evading the hypothetical," but how would we incorporate that into the kind of argument that judges and lawyers would recognize as a legal argument.

Seidman: That response circles back to the fact that we are much better off for having more women in the classroom. Their presence fosters a more Amy-like approach. I'm bracketing here all the problems with the generalizations that Gilligan engages in, but this is in some sense a more feminized approach to law.

Tushnet: Again, as a sort of sociological matter that may well be right. My view of the history of jurisprudence is that Karl Llewellyn saw this all in the 1940s and 1950s. 9 It was there, it was available but for a whole variety of reasons it didn't become the center of the way people thought about law.

Seidman: And maybe it's become more of the center because of the women in law. I am a man and that makes me at best ambivalent about what you are describing. It does seem to me that there is some value in starting with a stark, decontextualized choice and figuring out what the right answer would be and then moving from that to thinking about how it changes if you begin to contextualize things. That's the way classical Socratic method worked. The professor would start with this very stark choice and then would add facts and see which facts mattered and why they mattered. But there is just no question that that's really gone out of fashion. Students just wouldn't put up with it today as they did when we were students - a fact that relates to Kennedy's point about hierarchy. There were a lot of things we put up with that students today would not. And I guess I think that change is for the better. There is less passivity, less idealization of the faculty and more willingness to take them on.

Tushnet: It's not clear to me that there are differences. I once happened to be sitting in on a class, it was just by chance, in which the

see the problems as more complex and resolvable through cooperation and compromise, rather than through decisive, individual action.

9 Karl Lewellyn - The Common Law Tradition: Deciding Appeals (1961), presents Llewellyn's views in the full (and idiosyncratic) form. 
instructor had built an incredibly sophisticated sequence of discussion into the class. He said something at the beginning of what was a two-hour class. Then, he moved on to stuff that seemed completely different, but by the end of the class he had circled back to the thing he had begun with. It was brilliantly constructed.

At the end of the class a delegation of students went to the Dean and said that the stuff he had said at the beginning of the class and at the end of the class showed that he was irresponsible as a person and he shouldn't be allowed to teach students. I had 20 years of experience in teaching and I could see the brilliance of what he was doing, but if the students couldn't see it, maybe it wasn't as brilliant as it seemed to me. So from my point of view, it was an unbelievably successful class, but from a pedagogic point of view it turned out to be a failure partly because it wasn't responsive to the student population as it was.

That relates to a point we haven't talked about: everybody refers to the movement to students as consumers. Law schools are much more likely to see students as people to whom they are selling something and whose values and interests must therefore be satisfied. And my experience as a law student was that the Yale law faculty couldn't have cared less about students.

Seidman: There is an upside and a downside to that. First of all, you're certainly right that that is going on. I think that's directly tied to this collapse of faith that we're doing anything serious. In 1968 the faculty thought it was doing something serious, it was doing something important, it was right, and if the students didn't like it, that was because they were kids and they just didn't understand. If you think what you're doing is stupid and worthless then you might just as well just make people happy and do things that students enjoy.

What makes this complicated is that the 1968 faculties might have been kidding themselves or in denial, and that what they were doing really was silly and worthless. If that's true, then it's a good thing that their pretensions were punctured. But I guess I do think that if there were as you say a revived sense of the integrity of what we were doing, perhaps because we were doing something different, that would lead to a decline in consumerism because then we would care again and have some faith again that, whether the students understood it or not, this was something worth doing.

Tushnet: Two things. One about the past and one about the recent developments. Although this was not something I then fully understood or appreciated, one of the great events in Yale Law School when I was there occurred when a bunch of students set up a commune in the courtyard of Yale. They just moved and lived there. It was a hippie commune of law students. That's a little weird, but in the law school, it was a challenge to the seriousness 
with which the faculty took itself. On reflection I now think it was more significant than the directly political stuff that I was interested in.

Second, on modern consumerism: It's worth distinguishing things that make the experience of living in a law school more pleasant. The joke at Harvard is that the Dean of Students office always has a bowl of candy out or that Elena Kagan supplied bagels and coffee. When I started at Georgetown, the Law School was in one incredibly over-crowded, unattractive building. Now there is a campus and because people are physically located in space, the experience of being located in the space of the Georgetown Law campus is just better than it was 30-35 years ago. Similarly with Harvard, which opened in the past five years or so a big new building that has lots of spaces for students. That is all to the good. What we're interested in/concerned about is the movement of consumerism into the classroom.

Seidman: I have a mild disagreement about the dichotomy you are drawing because the economist is always going to ask about opportunity costs. Georgetown spent lots of money building an athletic facility. The issue is complicated because the donor might not have given money for something else, but at least in principle, that money might have been spent on something else and if we took the things we were doing academically more seriously, the Dean might have pushed harder for spending more money on that and less for money for treadmills.

Tushnet: Well we do disagree on this. The athletic facilities are in part a product of the consumerist mindset. Students come from university settings in which they are used to having easy access to athletic facilities and it is a selling point that you can just walk across the street to use a facility, you don't have to go five blocks away, okay that's true. But there is the Latin phrase of healthy mind and a healthy body. ${ }^{10} \mathrm{I}$ think it is not outside the domain of concern of a serious academic institution that students are healthy across the board.

Seidman: Georgetown Law Center is a nominally Catholic institution and one aspect of the residual Catholicism there is the notion that we're educating the whole person. Frankly, that gives me the creeps.

Tushnet: I think it's one of the great things about Georgetown.

Seidman: So there you go. I think there is an important idea about jurisdiction here, and an educational institution that is concerned about the whole person risks totalitarianism. Universities ought not to care about the whole person. They ought not to care about my sex life or my views about religion or how I treat my neighbors. They have a very limited function. They care about education, about the mind, and so I don't know that it's necessarily a good thing that universities have athletic facilities. You know, as I'm saying

10 "Mens sana in corpore sano." 
this I understand how rigid it sounds, and I don't mean it quite as rigidly as it sounds, but I do think there are dangers in expanding the jurisdiction of universities over aspects of their students that are really not their business.

Tushnet: Here too I would say we might want to think about whether different institutions could assert different kinds of jurisdiction and in this context it's not irrelevant that Georgetown is an institution affiliated with the Society of Jesus and Harvard is not. It might well be that having a universe of 170 whatever law schools some of which take the care of the whole person seriously, others of which limit their jurisdiction, that might be a good thing. Call it institutional pluralism or diversity. You might well be right about Harvard, but I might be right about Georgetown. All law schools face this problem with respect to off campus behavior by law students in connection with non-law students, part of the \#MeToo movement and drunken behavior kinds of problems and we all struggle with it. And I'm not sure that we as the legal academy writ large needs to have a single position about the scope of our jurisdiction.

II.

Seidman: Let's talk about legal scholarship. Why don't you say something about how you think legal scholarship has evolved over the last 50 years.

Tushnet: I think the first thing to note is just a framing issue. Both of us are public law scholars and although I think we're both observers of what's happened in private law scholarship, we haven't been engaged in it in any intimate detail. So what we have to say about private law is less well informed than we say about public law.

There are two things that I would start with. One is about "doctrinal scholarship" and the other is about -- again broadly speaking -- empirical scholarship. The proportion of work in those two fields has shifted pretty dramatically over the past 50 years. When we started, there was empirical work going on in law and society stuff and the early stages of mostly theoretical law and economics rather than empirical law and economics, but the heavy predominance was of doctrinal work. Now the proportions are quite different. I would still say there is probably more doctrinal work than empirical work looking at what I would regard as serious and interesting scholarship, but the margin is much thinner than it used to be.

Seidman: I agree with that. Of course, the realists did empirical work of a sort. I think many people today would say it was pretty primitive, but in the last half century there has been the explosion of much more sophisticated empirical scholarship. People are better trained in empirical methods and are doing better work than they were. I'm still skeptical of a lot of it. There is still 
a problem about deriving an "ought" from an "is," but the work is certainly much more prominent and much more sophisticated than it was when we started. Indeed, when we started there was very little of it.

Related to that, when I think about how things were when we started especially in the public law realm, it seems to me the dominant form of scholarship was what I would call "oracular" or "wisdom" scholarship. With remarkably little empirical support for what they were saying, people developed grand theories -- except to call them grand theories itself is perhaps treating the work too kindly. Often there wasn't any real theoretical underpinnings. It was just people who thought of themselves as very smart and wise writing sweeping conclusions about law and the way the law ought to operate.

The decline of oracular scholarship is tied to something we talked about earlier -- the decline of confidence in what we were doing. In the 1960s and 70s law professors thought that they had something to say. They thought that they were really smart people, they were sensible people and that just saying what was smart and sensible would be useful to readers. There is a fair amount of that now, but there is less of it, and that has caused a movement toward counting things and looking at empirics rather than at values.

Tushnet: I have a couple of thoughts in response. One is that I have come to be more respectful of what you are calling the oracular enterprise than I was earlier in my career. There is more to be said for it than I used to think. Scholars engaged in that enterprise were in their view exhibiting the quality of judgment that they thought, and I now think, is properly regarded as an important component of legal analysis. One of the things that the field of legal scholarship has not really tried to figure out is what we mean when we say somebody exhibits good judgment.

I recall a paper that Bob Pitofsky gave some time in the 90s or late 80s which was in the oracular mode, but which was I thought an impressive exhibition about how someone with deep grounding in experience and relatively speaking thin theoretical sophistication could say things that were worth paying attention to because he was a person of good judgment.

Seidman: I think we disagree at least to some extent about this. As you say, much of this work by a lot of famous people was under-theorized. It was just their so-called good judgment about how things ought to be. Because it was under-theorized it was not very well defended. I think of Henry Hart in this regard. What it amounted to was saying this is how sensible people view the world, and if you don't view the world this way, we don't really have to explain to you why you're wrong. It's just that you're not a person of good 
judgment. That was in some sense authoritarian and it cut off a lot of discussion that might have been useful on the part of people whose good judgment was different from their good judgment.

Tushnet: I think that's right and the only response I give is that what counts as theorization is itself contestable. What sophisticated oracular people would say is that your theoretical account almost by definition rules out of consideration things that actually affect how the real world works.

Seidman: Of course that's a real problem, and I guess law and economics famously illustrates that.

One thing that happened during our career was that at some point there was a reaction against this oracular scholarship and the exclusionary nature of it. One direction that that went was toward theorizing, using economics as a touchstone. Another direction that it went was with the development of writing very nontraditional scholarship associated with feminist thought and with critical race thought where all sorts of things began to appear in law reviews that never would have 20 years earlier -- short stories, vignettes, argument that was not at all in the traditional form of legal argumentation.

My own sense about that is that in terms of our career, nontraditional scholarship occupied a kind of a middle period, but that it is now fading again. There is much less of it in law reviews than there used to be. I'm wondering what you thought of that kind of work at the time. Was it a good thing that it began to appear and is it a bad thing that there is less of it, if indeed there is less of it?

Tushnet: I famously was taken to be critical of that turn in legal scholarship. ${ }^{11}$ My own view, maybe badly expressed in what I wrote, was that it represented an extremely interesting and exciting opening up of the space of scholarship. People were able to communicate things, communicate ideas that were much more difficult to communicate through their traditional modes of legal scholarship and what they were saying was interesting and valuable and in some ways inextricably connected to the mode in which it was being put.

I agree that it has faded somewhat, maybe even quite substantially. Certainly the innovative forms appear significantly less frequently than they did. I see part of this at least in political terms and reflects my experience with critical legal studies. Critical legal studies started at a time when liberal domination of policy in political discussion was fading, was weakening.

11 The reference is to Mark Tushnet, The Degradation of Constitutional Discourse, 80 Geo. L.J. 251 (1992). 
Liberals responded to Critical Legal Studies by saying, "All you are doing is weakening us when we need to be strengthened against the rising tide of conservatism."

At some point the political environment changed at least within the law schools, partly due to critical legal studies. The defense of liberal legalism was less urgent either because it was so well established or because it didn't really matter. That meant that space became available for these alternative ways of addressing things. Now, with the resurgence of conservatism, particularly in the post-Bush form, the need to defend legal liberalism seems to be back on the table and so the space for alternatives has narrowed.

Seidman: Yeah, it is striking that there was a period when the standard liberal discourse was really on the defense from both the right, principally in the form of law and economics, and from the left, principally in the form of critical legal studies. It looked for a while like there was not much space for the kind of standard mainstream moderate left of center legal analysis.

I think that is something that has changed dramatically with the emergence of a much more powerful and much more sophisticated and better theorized conservative view of law that has elicited more standard liberal scholarship in response.

You are too nice to say what I would say about the alternative forms of scholarship that we've been talking about. In principle that kind of work is exciting and it had the potential to open up space for doing really interesting and innovative transgressive sorts of work. There was some that. Some of it was quite interesting. My problem was that most of the people who were doing it just weren't doing it very well. A lot of it was tendentious, question begging, not convincing. Of course, part of the move was to raise questions about what we took to be convincing, what was necessary for something to be convincing, but I guess I would just have to say I wasn't convinced. I wasn't much moved by it, and that seemed to me a lost opportunity because if the work had been better it might have really opened things up in a way that it failed to do.

Tushnet: The way I think about this is there is this thing called Sturgeon's law, originally in response to criticism of science fiction. Theodore Sturgeon, a science fiction writer, said, 90 percent of everything is crap. ${ }^{12}$ Since

12 "I repeat Sturgeon's Revelation, which was wrung out of me after twenty years of wearying defense of science fiction against attacks of people who used the worst examples of the field for ammunition, and whose conclusion was that ninety percent of SF is crud. Using the same standards that categorize $90 \%$ of science fiction as trash, crud, or crap, it can be argued that $90 \%$ of film, 
you know that 90 percent of $\mathrm{X}$ is crap whatever $\mathrm{X}$ is you want to look at is the 10 percent that is interesting.

Seidman: Fair enough, fair enough.

Tushnet: I wanted to say a couple of other things in quasi-defense of the oracular style and then one real challenge to it. One of the things that was true of public law scholarship when we started was that it had a certain kind of integrity. It made sense when you put it all together. You could say well here is this thing that doesn't fit in very well but if we tweak it you can see how it fits in. Or you could say this was just an aberration that we should be able to bring under discipline by the exercise of careful reason. The critical legal studies and legal realists tack on that was well no it didn't have that kind of integrity. There were a variety of reasons why it didn't, but one thing that project licensed was a set of normative judgments that were for a long time not unattractive. Then when their political valence shifted it became apparent the judgments no longer seemed quite as valid.

You mentioned Henry Hart. As you know, he was the author of this famous dialogue about federal jurisdiction. At one point in the dialogue, he's working with the Supreme Court cases about fairness in adjudication and who can hear what kinds of cases. He's got a scheme that makes sense of everything. Then there is this one case involving immigration which he just can't make sense of. It's an awful case. From today's perspective, we would say it's an awful case. He thought it was an awful case, and so the interlocutor says well what happened? And his line is one of the most powerful in legal scholarship. He quotes from the Bible -- there grew up a generation that knew not Joseph. ${ }^{13}$ The people who were in charge just lost sight of what the enterprise was. Having a notion that there was an enterprise that had a point that was normatively valid was a very powerful orienting device.

literature, consumer goods, etc. is crap. In other words, the claim (or fact) that $90 \%$ of science fiction is crap is ultimately uninformative, because science fiction conforms to the same trends of quality as all other artforms." Venture 49 (Sept, 1957).

13 "There arose up new justices in Washington which knew not Joseph. Citing only the harsh precepts of the very earliest decisions, they began to decide cases accordingly, as if nothing had happened in the years between." Henry M. Hart, The Power of Congress To Limit the Jurisdiction of Federal Courts: An Exercise in Dialectic, 66 Harv. L. Rev. 1362, 1391 (1953). Hart was making reference to United States ex rel. Knauff v. Shaughnessy, 338 U.S. 537 (1950) as well as Shaughnessy v. United States ex rel. Mezei, 345 U.S. 206 (1953); Ludecke v. Watkins, 335 U.S. 160 (1948); and Harisiades v. Shaughnessy, 342 U.S. 580 (1952). 
Now one of the things that happened was that it turned out that at the very least the people who were committed to that vision -- maybe not the vision itself but the people who were committed to it --found themselves tied to the post-World War II American imperialist project. When Vietnam came along, there they were using these techniques to defend the imperialist enterprise. What captures this is that Eugene V. Rostow makes his career with his early article on the Japanese American internment cases, calling the cases a disaster ${ }^{14}$ and then he ends up as Deputy Secretary of State or something like that ${ }^{15}$ defending the Vietnam War.

Seidman: All that seems right to me and quite insightful. What you are talking about actually goes back quite a long way. The attraction of Langdell in the very beginning was that you had a normative standard that was internal to law. Before Langdell, people were learning law in law offices. Langdell's approach had some normative bite to it. You could say these cases are right and they fit within this practice that we're engaged in, but then there were these other cases that were outliers that were just wrong. You could criticize them because they were contrary to standards that were internal to law.

That kind of analysis was still common when we were in law school. That is essentially what Henry Hart and people like him were doing. As part of the general loss of faith that happened pretty early in our careers, it no longer seemed sufficient that the normative basis for judgment was internal to law.

There were two things that happened or maybe two ways of explaining what happened. One is that the boundaries of what counted as law began to expand. Maybe for example Martin Luther King and civil disobedience is really part of our legal tradition and provides part of what the law is. An alternative way of saying the same thing is that people began to wonder why it was that normative standards had to be internally derived. That question gave rise to a desperate effort to find some other normative grounding -- a place to stand where you could criticize things and not just say that whatever happens is fine. That's a part of why law and economics was so attractive to so many people. It seemed to provide an alternative grounding.

14 Eugene V. Rostow, The Japanese American Cases - a Disaster, 54 Yale L. J. 489 (1945).

15 Rostow served as Under Secretary of State for Political Affairs from 1966 to 1969. 
Tushnet: I would say an alternative but in a certain mindset nonnormative grounding. It was science, it was the way the world was that was determining all this.

Seidman: Law and economics has a positive and a normative aspect to it. Certainly one of the projects of law and economics was to describe the system in terms of economic incentives, but there was also a pretty clear normative aspect to it. To put it very crudely the law and economics people thought that whatever your other views, something that we could all agree on was that waste was bad. Dead weight loss was not a good thing. So you wanted the law to be efficient to avoid waste.

Obviously, there were many, many problems with this approach, but in a world where the oracular approach had been discredited, where people no longer thought that just legal practice provided enough normative grounding, law and economics was an alternative. An advantage it had was that it seemed pretty simple and, to some people at least, non-controversial. It was also able to generate a research program. In terms of the sociology of legal theory, it's important that you have a theory that develops a research program. And so law and economics took off. It wasn't coincidental that it also supported conservative views and provided something of a defense of the status quo. But it does seem to me that its growth was part of a broader collapse of faith that also has affected law teaching and the law curriculum. Maybe that is the most important thing that's happened in the 50 years that we've been doing this.

Tushnet: My sense is that the assertion that law and economics normative claims were thin and non-controversial was decisively challenged very early on. There was exchange I think in the Journal of Legal Studies in which the central piece as I recall was by Richard Posner and was called Is Wealth a Value? And ...

Seidman: Dworkin.

Tushnet: Dworkin and people piled on to him in a completely effective way. ${ }^{16}$ The claim that wealth was a value just didn't survive. At the very moment when law and economics was asserting these things, its foundations were simultaneously being quite effectively challenged. That leads me to the conclusion that it's that other stuff -- the support of the status quo, policies congenial with conservative preferences -- that was doing the work.

16 See Richard A. Posner, Utilitarianism, Economics, and Legal Theory, 8 J. Leg. Stud. 103 (1979); Ronald M. Dworkin, Is Wealth a Value, 9 J. Leg. Stud. 191 (1980). 
I want to go back to something you said earlier about judgment and sensible people. You said that if someone didn't agree with a judgment then she was by definition not sensible and therefore the person hadn't thought things through well enough and so the oracles didn't have to take her seriously.

I want to assert that those people could do that only when by their own standards the people who were disagreeing with them weren't worth taking seriously. What happened was along came Richard Posner, Duncan Kennedy and Roberto Unger, and they just couldn't dismiss them as people who were not smart enough to have thought this stuff through.

That opened up a lot of space for people who are not as smart as Duncan and Roberto and Posner to operate. It took away the sting of the charge that your proposal is so far out of the mainstream that it can't possibly be well founded because here are these people who were saying whacko things. The centrists couldn't figure out what was wrong with what those three people were saying. They knew in their heads in some sense it was wrong but the resources they had available were just not adequate to explain to them on their own terms what was wrong.

I should say within a couple of years Kitty McKinnon was in the same category.

Seidman: So another qualification and it's just a qualification. I think that the way you've put it over-emphasizes the intellectual aspect of this and under-emphasizes the extent to which what we're talking about is power. It mattered a lot that Posner, Kennedy and Unger they were at the University of Chicago and Harvard. They couldn't be dismissed, because they had somehow gotten into this elite circle. If they were writing the same thing at the University of Iowa it would have been easier to dismiss them.

Tushnet: I just want to interject one point, which is that one of the things that I was struck by when I was bureaucratically running the Conference on Critical Legal Studies was how much really interesting work was being done by people at non-first-tier institutions. The Critical Legal Studies Conference was a network and the network had nodes or individuals scattered all over the country.

Seidman: That's undoubtedly true but what mattered in the end -what shook people up -- was that these people were at Harvard.

Tushnet: There is no question about that, I just wanted to support . . 
Seidman: You're absolutely right about that. But there is some tension between your saying that Posner's piece on wealth maximization was completely discredited early on and your statement a moment ago that Posner was really important in shaking up the liberal dominance. I actually think Dworkin's critique of Posner was less effective than you think it is. It requires some modifications of the argument and I do think the argument ultimately fails. But I don't think even today that it's just completely rejected. Even today, some people still implicitly or explicitly adopt something like Posner's wealth maximization ideas even though Posner himself has moved away from them. I'm going to change the subject a little and talk about a hobby horse that I have so ...

Tushnet: I want to hear this because I may want to defer it, so what is your hobby horse...

Seidman: My guess is we're going to be in agreement about this but we'll see. When we were talking about the student experience, one of the things we talked about was the unique role of the law schools in the university. One of the great strengths of law schools is that they straddle the real world of practice on the one hand and theory on the other. They are not philosophy departments and they are also not teaching plumbing. But there were pathologies associated with this middle position. The pathologies existed when we started 50 years ago but I think they're worse now than they were then.

The particular pathology I have in mind is what you referred to as "corruption" in a great and courageous book review you wrote a long time ago. ${ }^{17}$ I think the kind of corruption you were talking about is very widespread and very disturbing. We have a class of legal academics who on the one hand are in the university, but on the other hand they are arguing cases before the Supreme Court and placing their students in Supreme Court clerkships. They are very attuned to the power structure, and that affects what they say and write. They don't want to write a law review article that is going to get in the way of some argument that they are making in the Supreme Court.

17 "The question ... is to what activities the rewards of ambition accrue. In the world of public affairs, they accrue not necessarily to intellectual substance. One who addresses the real questions of justice is by that fact alone disqualified from serious consideration for public position and influence, because raising those questions raises in turn questions about the worth of the positions that now exist, to be occupied or influenced.... [T] he Framers would have understood the phenomenon . . . they called it corruption." Mark V. Tushnet, Dia-Tribe, 78 Mich. L. Rev. 694, 710 (1980). 
The worst thing that can happen to you -- and it does happen sometimes -- is when somebody stands up and is making an argument and a Justice says "but you said the opposite in some law review article." You also don't want to offend people in power because maybe you are thinking about going into the next Democratic administration or you want Justice Alito to hire your students as law clerks.

That affects what these academics say in law journals. They sign amicus briefs and letters and statements that trade on the fact that they are academics and so suggest that they are engaged in an academic enterprise when sometimes I don't believe they've read the briefs that they've signed and, in any event, they are signing them for instrumental reasons and not because as academics they think it's necessarily the right outcome.

Now it's complicated because that goes with the territory of being in this middle position, and I do think that's a strength of law schools. We don't want to turn them into philosophy departments. At the same time, there is something that I find disturbing about it. I think it is very prevalent, and you had the right word for it -- corruption.

Tushnet: I don't disagree with much of that. Just note two things. One sort of point of personal privilege I don't sign things that I have not substantially contributed to the writing of ....

Seidman: I don't either, which means I sign almost nothing.

Tushnet: Right. The other is a point that Sandy Levinson made sometime in the 1980s. I wrote an article that had a line saying if I were a judge I would decide a case in a way that would advance the cause of socialism. ${ }^{18}$ Sandy said that was great because it would disqualify me from any aspirations of holding a policy position in a Democratic administration and so I could say whatever I wanted afterwards. My footnote is, but if I live long enough Alexandria Ocasio-Cortez is there for me to latch on to.

I want to distinguish between some things you said. What you were describing led me to think of W.E.B. Du Bois's description of blacks as having a dual consciousness both as black and as Americans. ${ }^{19}$ Now, obviously, he was talking about a quite different situation, but it is possible for academics to have that kind of dual consciousness. They can write deeply critical work, challenging the presuppositions of the legal system or some doctrinal areas and

18 Mark Tushnet, The Dilemmas of Liberal Constitutionalism, 42 Ohio St. L.J. 411 (1981).

W.E.B. DuBois, The Souls of Black Folk, 3 (1903). [check cite] 
write academic articles that take those presuppositions for granted and work with them. The jurisprudence associated with this gets very complicated, but I can simultaneously say the foundations of first amendment doctrine are deeply flawed in the following kinds of ways and say, given existing first amendment doctrine, it would be constitutionally permissible for Congress to ban Facebook from distributing fake news. Now as I say there is a jurisprudence -- you're shaking your head -- but there is a jurisprudence associated with the latter...

Seidman: I'm not disagreeing with that, but that's not what I've described.

Tushnet: Right, no, so you're describing somebody who does the first thing and the second thing but then also advocates well ... pulls his punches.

Seidman: Let's just put this very crudely. There are a fair number of academics today who would like to be federal judges and if you would like to be a federal judge then you are thinking about what your confirmation hearing is going to look like, and given the way confirmation hearings work now, you can count on the fact that stuff you put in Harvard Law Review is going to be read back to you and of course that has an effect on what you put in the Harvard Law Review and that is very troubling. I think that's quite different from somebody who stands outside the doctrine and criticizes it but also makes an internal critique. That's very different from shading your views about either the doctrine or the critique because of your ambitions to hold power.

Tushnet: My characterization of the people you have in mind is that they have so deeply internalized their, as you put it, aspirations for a position that they don't in fact pull any punches in their academic advocacy or in their academic work because they don't see those punches as actually being available.

Seidman: And that makes it even more insidious. There are people I know who have modified law review articles because they are worried about how they are going to be perceived and what effect they are going to have on their careers, but at least those people feel some internal tension about doing it. If it's all already resolved unconsciously so you don't even feel the tension, that's even worse. Then we're really in big trouble.

Now I do have to say this: if you take this kind of critique really seriously, it cuts more deeply than I'm acknowledging. It's not as if any of us write things under circumstances where we are unaware about the effects that it has other people. People also have to get tenure, so they are worried about what the tenured faculty is going to think about what they write. People who 
have tenure are not immune from desire for praise and maybe they have a different audience that they are appealing to. So I acknowledge it's not possible to get completely outside of this sort of thing. All of us are motivated by it, but there is a special problem when what motivates us is a desire to be accepted by the people who exercise the most power in our society -- by people in government -- by people who are in control of the status quo distributions of power. What bothers me the most about is that I don't think many people are even troubled by the problem. It's just there and people don't worry about it to the extent that they ought to.

Tushnet: It occurs to me that here as before our location at elite institutions may affect what we're saying in a fairly dramatic way. I think about a fair number of people who I know who teach at less elite institutions whose aspirations are for local influence and position and whose scholarly work is not distorted by that aspiration. Indeed it may even be enhanced by it because they will write about things that matter in their jurisdiction, in their city, in their state and will know about those things in a way that they can build into their scholarship. Maybe they don't have to worry about what is going to happen at the Senate confirmation hearings because that's not going to happen to them.

Seidman: That's a really interesting observation and it suggests a paradox. Maybe the scholarship we ought to be paying the most attention to is scholarship written by people at institutions that are less well known because it's less likely to be corrupted in a way that scholarship at other institutions is.

Tushnet: Yes, but it's also produced under constraining circumstances, other kinds of constraints.

Seidman: And I do think it's worth pointing out it's not as if any of us are somehow removed from the matrix of power. The really cynical view, which I believe on alternate Wednesdays, is that all of it is just the product of the matrix of power. It's just that different sorts of people are exercising power over the different classes of people.

Tushnet: A footnote here: one of the things that the critical legal studies network did and to some extent still does because the network is still sort of around even if the organization isn't, was to provide a sufficiently strongly alternative source of power for these sorts of validation purposes like getting tenure. It allowed people to do stuff while weakening the concern about tenure. If you knew that five people at Harvard, Stanford and NYU could write tenure letters for you because they knew your work... 
Seidman: And just to circle back I suppose one of the virtues of the nonstandard scholarship that we talked about earlier -- narrative scholarship -- is that it peeled away this façade of objectivity and the pretense that what was written was outside the matrix of power. I have contradictory and mixed feelings about that because on some level I also value objectivity. I'm not ready to completely give that up, so in some moods I think we ought to hold on to the ideal of people writing what they perceive the truth to be. But I can also see how that is really a façade and if you are writing a certain kind of short story rather than a law review article with lots of footnotes, it does convey that this is situated and not oracular and that's a virtue.

We haven't talked about one other thing that occurs to me that is really unique with regard to legal scholarship and has survived for these 50 years, and that is the fact that students are the people who determine what gets published. There is usually not peer review. There are more peer reviewed journals now than there were 50 years ago, but the norm is still student editors and I wonder what you think about that.

Tushnet: I don't have strong views. One advantage of student edited law reviews is that they are accompanied by subsidies from the law schools so that the law reviews don't have to be financially self-supporting. That's a significant factor, and it differentiates law publishing from publishing in the sciences where journal prices are as you know ridiculous because of the economics of private publication.

My general view is that the subsidized, student edited model is pretty good for legal scholarship because to put it in the sort of least attractive way, anybody who writes something that has some degree of seriousness can get it published somewhere. Then, once it's published, disseminating it is much easier. A footnote here: the availability of dissemination over the Internet has changed things to some extent but some even modest degree of screening by somebody else as opposed to self-publication which is what you can do on the Internet has some advantages

Seidman: I wonder about that. If the virtue of the law review system is the absence of screening then you could really get rid of the screening. You could just have people put things on SSRN. I wonder exactly what the law reviews are adding to that.

Tushnet: Yeah, except that SSRN is itself a profit maker. It is financed by somebody.

Seidman: But SSRN will literally put anything up. 
Tushnet: You have to have access to it and so that it means you have to be a member. Your institution has to join.

Seidman: But they are not screening.

Tushnet: They are not screening for quality.

Seidman: And the screening that law review editors do strikes me as kind of random and arbitrary.

Tushnet: I think that's probably sort of right but while it is unpredictable in any specific instance, I'm not entirely sure that in the aggregate it's arbitrary, I'm just not sure.

Seidman: Sometimes it can be both arbitrary and insidious at the same time. I worry about its insidiousness because student editors tend to be risk averse - more so than they used to be. If there is something they see that just doesn't fit with what they are used to seeing, that is screened out.

Then there is also the really annoying editing process. I don't want to overly generalize. I have had great edits from student editors, but there is a level of obsession with technical rules as opposed to really trying to make the argument better -- especially on lesser law reviews -- that is frustrating and annoying.

Tushnet: My attitude on that is unless they want to change the idea they can do whatever they want.

Seidman: Oh it's fine if they do it; the problem is if they want me to do it.

Tushnet: Well right.

Seidman: I think we talked a little bit about this last time, but the experience of students on law reviews is really unfortunate. They spend huge amounts of time doing work that is below their intelligence and education and that they don't gain anything from -- mastering stupid Blue Book rules. They don't spend nearly enough time engaging with the ideas in the articles that they are editing or writing articles of their own. The only reason students put up with it is because of the resume value. So when you want to talk about corruption that is another source of it.

Tushnet: I'm less exercised by that. I do want to go back to this screening enterprise. I used to read incredibly widely in law reviews. I've 
scaled back over the past five years or so, but I remember one particular incident where maybe because of the title of it, maybe it seemed to be something I was then currently interested in, I read an article -- I'm pretty sure it was in the Utah Law Review -- which is not a main line journal. It's the main journal at the Utah Law School but it's not on the top end list of journals.

The article was a spectacularly good piece of subtle doctrinal analysis. The authors saw something in a bunch of cases that unified them and explained them really well. It was just one of the best articles that I had read in a couple of years. ${ }^{20}$

I wrote something about the article, saying how good it was. I later found out that it had survived the first level of screening at the Yale Law Journal. Then, at the second level they decided it wasn't original enough for them to publish. That was a mistake in judgment on their part. They don't know the field in the way that I knew the field at the time. I knew that this was a real significant piece of work. But it got published and it's available.

Seidman: Yeah so that is really a virtue of having so many journals in lots of fields. The piece would not have been published if there were only a handful of journals. On the other hand, you can read the story the other way. I assume the authors submitted the article to many, many journals and so this really brilliant piece of work was turned down by many, many journals. That raises questions about the judgment of people who are doing the screening.

Tushnet: Well right. They themselves were operating under a bunch of constraints, a limited number of spaces per year, some obligations to the favor of folks of their own institutions, so whatever. I mean I'm not overall troubled by the publication structures available in law.

Seidman: There's another virtue that is implicit in what you're saying but deserves to be made explicit. The fact that there are so many journals and the fact that students who are not fully acculturated are running them provide some check against orthodoxy. A student at Yale can just think gee this is really interesting and it ends up getting published whereas in other disciplines, it would be screened out because it is just too far removed from the standard way of thinking that people have.

Tushnet: I want to get back now to one of my hobby horses. Within our discourse, empirical research is normally defined as quantitative research. If you do historical work it's not called empirical, it's called legal history. If a law

20 Brannon Denning \& Michael Kent, Anti-Evasion Doctrines in Constitutional Law, 2012 Utah Law Review 1773. 
school wants to hire one or two legal historians, it's fine, but they are not seen as doing empirical research. At least legal history is a reasonably well established field, but ethnographic or anthropological investigation of how institutions actually operate is not strongly valued in elite institutions. This is a continuing lament among people who are associated with the law and society movement and it's accurate.

If you are investigating $\mathrm{X}$, if you are investigating police community interactions a study that extracts data from arrest and similar records is highly preferred to a study in which the author hung out around a courthouse or rode with police officers or in a famous example rode around with criminals to find out what was going on. ${ }^{21}$

Seidman: Right so ...

Tushnet: And that's bad. Ethnographic stuff is empirical and valuable in ways that deserve more recognition.

Seidman: I think I agree that it's bad. Certainly the particular study you made reference to is arresting and really interesting, although perhaps ethically problematic. But what you are pointing to, I think, is a problem about internal rules within disciplines and what counts as good work and bad work within a discipline. When you have somebody engaged in a different discipline that violates the internal rules, it's a little hard to know what to make of that. With what is normally called empirical work, there are all of these checks that are thought to guarantee validity. The study has to survive different kinds of regressions. You have to have an "n" that is large enough. There are complicated, technocratic ways of judging whether the conclusion is accurate or not. The kind of work you are talking about just disregards all of that. Of course, it has other virtues. This is a problem with disciplines excluding things that are outside of themselves.

Tushnet: Well, go back to when we started. In 1960 empirical law and economics was not within the discipline of law.

Seidman: That's right.

Tushnet: So the field's standards appropriately changed so as to incorporate something new. My observation is our field's standards of evaluation have not changed appropriately to incorporate the ethnographic stuff.

21 Alice Goffman, On the Run: Fugitive Life in an American City (2014). 
Seidman: That might be a good thing or a bad thing. It's correct that disciplinary boundaries are always contested. There is an ongoing fight about what's within the discipline and without the discipline. This was a famous fight about critical legal studies, which was thought to be outside the discipline. ${ }^{22}$

I guess that battle was more or less won by critical legal studies, but here is the point that I think is actually troubling. Disciplinary boundaries are always contested, but I don't think it's a plausible position to take that therefore disciplines ought not to have boundaries. The boundaries remain at least contingently in place until the battle is won (if it is won), and those outside the boundaries are admitted into the tent, to mix metaphors. Right now the boundaries of empirical research are enforced by methodological standards like controlling for other variables and a whole lot of complicated stuff that I don't understand very well. Ethnographic research doesn't satisfy those criteria, so it's excluded.

Now you might say well that's bad, and it ought to be included but what I don't think you can say is and therefore there ought not to be any boundaries.

Tushnet: Oh no, I'm not saying ...

Seidman: The fight about where the boundaries are ...

Tushnet: No, no, I'm not saying that. I'm saying that the field of legal studies is less rich than it could be had the boundaries expanded with respect to ethnographic studies in the way they expanded with respect to quantitative studies.

Seidman: Let's say I have a new method called intuitive legal studies. I just intuit how the police are behaving. I suppose that somebody could say legal scholarship is less rich because it is just excluding these people who have intuitions about things. In some sense, I suppose, it is less rich, but, gee whiz, I'm embedded in a practice that excludes that material, and it seems right to me, so I'm happy to exclude it. Somebody who does statistical work feels that way about ethnographic work. They are just not playing by the rules, so there is no reason to pay attention to it.

Tushnet: Well there is a big literature in philosophy of science about these kinds of writings and my take on those controversies or my take-away

22 See Paul D. Carrington, Of Law and the River, 34 J. Leg. Educ. 222 (1984). 
from them is that the ultimate standard is fundamentally pragmatic. Does it seem like you have a better understanding of ...

Seidman: Seem to whom?

Tushnet: Seem to people in the field as an aggregate. Wait Mike, wait. You started out in the 1960s where people in the field didn't think that statistically valid quantitative studies counted as legal studies.

Seidman: Right.

Tushnet: Somehow they changed their view. Okay, if they changed their view about that, there is an account of why that happened and it's not that that was science and ethnographic studies were not science. It was something else. Now what we want to find out is why there was a change with respect to quantitative studies that didn't occur, or didn't occur nearly as substantially with respect to ethnographic studies.

Seidman: A sociologist might say that this is a power struggle. There are people on the outside who want to get inside and sometimes they do and sometimes they don't. It is an interesting question why sometimes people have the power to do it and sometimes they don't. That's a view from the outside. From the outside perspective, we're just going to have to see how it comes out with regard to ethnographic studies.

Now if you try to get on the inside, if I'm somebody who does empirical studies, it is going to seem to me that this stuff is nonsense.

Tushnet: The kind of person who does quantitative studies.

Seidman: Yes, it's going to seem to me that this is nonsense and so the people who do small "n" ethnographic studies, they are going to think legal intuitionism is nonsense. You're always within some sort of practice so maybe the intuitionists will prevail, and at some point somehow they will get into the legal academy.

Tushnet: All I want to say is that the observation that quantitative studies became understood to be within the field of legal studies as a result of some power relations doesn't have to be end of the discussion.

Seidman: No absolutely not.

Tushnet: You might want to ask what were the forms of power ... 
Seidman: And you might want to ask that about intuitionists also ...

Tushnet: Right, right

Seidman: Or about flat Earth people or ...

Tushnet: But that is the philosophy of science discussion.

Seidman: Right, right.

Tushnet: My favorite example here is from Paul Feyerabend. He has this thing about witchcraft and it's very powerful. He ultimately suggests a pragmatic resolution. We in the field as an aggregate can do two things. One is to ask ourselves whether when we look at these ethnographic things we think that we know more about law after reading them than we did before. Or second, why is it that the gatekeepers have decided that the increment of knowledge from the ethnographic stuff is less than the increment of knowledge from the quantitative stuff? What is the understanding of knowledge, what is the power/knowledge nexus ...

Seidman: So they would have things to say about it ...

Tushnet: Who the ...

Seidman: But the problem is it's always internal to some practice. You can't get outside of all practices. So people within a certain practice would have things to say about it, but what they said wouldn't conform to the conventions of people within a different practice. That's always going to be true. It's true about witchcraft, it's true about intuitionists. That's just the human condition.

Tushnet: I'm thinking about this partly in connection with the comparative constitutional law field where there is now a significant intrusion of large "n" studies which are significantly less illuminating to me, a person in the field, than the small ...

Seidman: In $a$ field ...

Tushnet: Right but at some level I am a gatekeeper in the field. In that sub-domain my pragmatic judgment is the quantitative stuff, empirical stuff has been less valuable than other informative inquiries.

Seidman: But this is not the view from nowhere. You are embedded in a particular version of the practice and within that particular version this stuff 
seems useful to you. If you were embedded in another discipline or another version of this discipline then it wouldn't seem useful.

Tushnet: Yeah but at some level then we could go back to the beginning of the conversation tonight and erase it, right, because we're evaluating 50 years of ...

Seidman: We're always some place, that's right, but I guess the only point I want to make and it really is just a caution: it doesn't make sense to say there are no boundaries to a discipline. The boundaries that are drawn for a discipline are always going to seem arbitrary and exclusionary to people on the other side of the boundary. If you are on the other side of the boundary you are going to say gee whiz this intuitionist stuff -- the law could learn a lot from that.

Tushnet: Or just to go back to earlier stuff. What's wrong with the oracular style and why is the stuff that you and I have called corruption corrupt?

Seidman: That's right so, this is probably a good place to end. There is a real question about how we know anything, and we're not going to resolve that tonight I don't think.

Tushnet: That seems reasonable.

III.

Seidman: It strikes me that a good way to end this conversation is by talking about the fact that both of us are at the end or close to the end of our careers. I remember how I felt about people who were our age now, when I was beginning. I did not have a high opinion of many of those people, and I am reasonably confident that people who are now my age when I was beginning don't have a very good opinion of us and ...

Tushnet: The ones who are still alive.

Seidman: And that is disturbing.

Tushnet: My perspective on this is shaped by a particular facet of this conversation, which is that with the exception of my period in Wisconsin, we're talking about a single institution, Georgetown, early Georgetown. One thing that happened around the time you were hired -- I was sort of at the tail end of it -- was that Georgetown changed from being a good local or regional law school into being a national law school and the characteristics of faculty members of those kinds of schools are quite different. 
The faculty in place at Georgetown when you and less so when I arrived was a very good faculty for a local or regional law school, but it was not a very good faculty for a national law school at that time. I think one of the remarkable things about Georgetown was the way in which Dave McCarthy, ${ }^{23}$ who was embedded in the Georgetown culture, was able to manage the transition from a regional law school to a national law school and, importantly, to get the then older faculty to go along with the transformation whose effect was to bring on faculty members who they correctly understood would not regard what they had done as major contributions to legal education or scholarship.

Now that's our experience and one question that occurs to me is what do the youngsters now think of us as we approach retirement. Let me put it this way: for our entire careers Georgetown and, of course, Harvard have been national institutions so that the old codgers on both faculties have the characteristics that the youngsters think appropriate for national law schools.

Seidman: I certainly agree with you about the evolution of Georgetown Law Center and the crucial role that Dave McCarthy played there, but I'm afraid I have a much bleaker view more generally about where we are and what happens when one becomes an old codger.

First of all, my disdain for people who were my age then was not just about people at Georgetown; it was about people at national law schools, including Harvard, who seemed to me to be living a kind of lie or at least not understanding the truth about what they were doing. I think a lot of people young people now think that about us -- that we are out of touch, we are associated with ideas and emotions of movements that are long passed, that we need to be replaced. It's a very uncomfortable feeling to have.

Now one might expect someone to develop some tolerance from this experience. I can imagine one saying, well I felt that way then and so there must be something to what they are saying now. And in a part of my brain, I can see that the problems today are not the problems of the 1960s. And yet I can't quite get out of my mind the idea that the young people are wrong, that they don't understand things that we understand. Of course the very disturbing thing is that is exactly what the old codgers thought 40 years ago about us, so I don't know quite what to make of it.

23 David J. McCarthy was dean of Georgetown University Law Center from 1975 to 1983. 
Tushnet: What do you do when a younger person sends you something, how do you respond to it? In the early stages of our careers it was unusual for the senior people to respond in a generous way except for people who they regarded as their own protégés. Now your account is the thing to do is to engage the young people on their own terms, say from our perspective "here is how what you are doing could be improved, there is a view of the topic that you might want to think about even if you are not going to incorporate it in the thing that you sent me" and so on.

I think that's fine. There is this sort of purely logistic problem. The shift from distributing things via paper and what we now call snail mail to distributing them via e-mail and electronically means that it's much easier for people to send you stuff and ask for comments on it. That's a hassle; you want to figure out some way to say particularly if it's something you're not wild about, you know, "I read it, it's interesting, I can't really engage with it too much more because of all the other stuff I'm doing," but that's a question of technique more than of substance.

There are also pedagogical aspects of aging that are tricky to handle. Cultural references become much more difficult. You can't count on your students having access to the same kinds of cultural references that you want to make.

Seidman: I would put it the other way. We don't have access to the kind of cultural references they have.

Tushnet: Fair enough, right, there is a discrepancy between access to cultural references. The way the older generation handled it was by confining the references to truly classical things like $19^{\text {th }}$ century things where you don't have to assume that the students know what you're talking about when you talk about oh the litigation in Jarndyce v. Jarndyce as an illustration of how long and complex litigation can be. I'm not sure that would be an appropriate reference at any point but the fact that this has entered the canon and remains there, makes it possible to make that kind of reference.

Seidman: The problem about being old is what was in the canon isn't in the canon anymore. I don't know how many students actually would understand the reference to Jarndyce. ${ }^{24}$

Tushnet: No and so I think my claim is not that they would understand it, but they wouldn't feel that I was out of touch by making that reference.

24 The doubt leads to the following reference: See Charles Dickens, Bleak House (1853). 
Seidman: I don't know.

Tushnet: Well so in a way that they might feel that I was out of touch in making a reference to, I don't know, the Beatles or say, I do movie references a lot, so a reference to the discovery of drugs in the rocker panels in "The French Connection", to make a point about searches and that sort of stuff. I'm pretty sure you couldn't do that now because "The French Connection" is a classic in some sense but not part of the canon, so you would have to think about what counts as part of the canon, I agree with that.

The other thing that is dramatic is that at our age we're just not able to use technology that is at our students' fingertips. I know cognitively that there are ways of using technology in a classroom that would improve the classes, but it's just too hard for me to learn how to do it at this point in my career. If I had another ten years of teaching I might try to do some of that stuff but it's just not worth it.

A classic example: in teaching statutory interpretation, there are cases where students split about what the right interpretation is. It's often interesting to be able to display to the students what the division in the classroom is. There are easy ways to do that, but I'm not very good at getting access to them, so that's a problem. My classes have Facebook groups, and there might be ways of using the class Facebook group pedagogically but I don't know what they would be and I don't have the time or energy to figure out what they would be.

Now, back to the concerns about being out of touch. Speaking from a political perspective, I don't believe that my fundamental views about politics have changed. They were correct early on, and they are correct now. The nature of the problems to which that politics has to be addressed has changed and it may be, I guess, when I think about some of these things, like, say, free speech controversies on campus, my view is that at the first cut the issues are typically more complicated than younger people on my part of the spectrum think they are. I suppose I could say that's the product of 50 years of experience with trying to think about how to deal with these things but I guess that's also sort of politic. Maybe I don't feel any dramatic deep push to revise my views about things, but I think my sense of complexity is probably deeper than it was early on. I don't quite know where this is going but maybe the way to put it is this -- this is wildly overly generalized -- but it may be that young people link my political views to the political/legal issues they care about more tightly than I think they should be. With experience comes a greater sense of complexity, a sense that the connections are looser than one's young self thought, and maybe 
that would be a description of what the old codgers in the 60 s and 70 s thought about us.

I guess my take on it is they may have thought that about us, but their political commitments were just not good commitments and so they may have been right that we were seeing the things that we cared about as more clear than they were, but they actually didn't think those were the things worth caring about. So the criticism was not entirely in good faith, I guess is the way I would put it.

Seidman: This conversation relates to something we talked about earlier and that is I suppose the obvious point that one is always standing some place and where one is standing inevitably influences what one thinks about things. The place I'm standing now and the view I have is influenced by a sense of the complexity of getting old, of being old, so it does seem to me that I know more than I used to know and I see that things are more complicated, and that I have something to contribute that young people might learn from.

One of the hardest things about getting old is something that Roger Angell has described in The New Yorker. He is now in his 90s, and one of the things he writes about is how people stop paying attention to him. He goes into a room at a party and nobody listens to him anymore. Of course we as law professors are used to being listened to. It's hard not being listened to, especially, if you feel that you still have things to say. Yet it is just true that the world changes and that the things that concern us and that formed our perceptions are no longer there. There is a reason in the end why people retire, why they leave, and ultimately why they die. There are new people to take over, new problems, and new perceptions about the world.

Tushnet: I'm puzzled by why that's bothersome. Two things occur to me, one quite general and related to my political views and the other quite personal. The general one is that I've always liked the title of Irving Howe's memoir, Steady Work. ${ }^{25}$ The reference is twofold. One is that working for a democratic socialism is steady work, you just have to do it all the time, but the other reference is you're never out of a job because there is always work to do. You do the stuff because it's part of this interminable project that you think is valuable. That seems to me fine and when you know it's a long-term project, which means that lots of things that you say are not paid attention to, but you think they're worth saying so you say them. The personal aspect of it is that I am in this quite peculiar position of having held a set of positions that were 20 years ago, 25 years ago, far outside of the mainstream -- and now they are out

25 Irving Howe, Steady Work: Essays in Politics and Democratic Radicalism, 1953-1966 (1966). 
of the mainstream but not so far out of the mainstream, and my view is that is because they are right and that is what you do. You talk about the stuff and offer views that you think are the correct way of understanding things, and then what happens happens. It's not under your control but you do what you can. So the fact that people stop listening -- so what. It's not a big deal.

Seidman: That sense that you've been vindicated must be a source of real satisfaction for you and I do understand that. It makes me wonder. In some sense what being on the left means is never being vindicated. If enough people now think it's the mainstream that means one ought to rethink one's positions because the mainstream is inevitably corrupt.

Tushnet: Well, compromised in a way that will always need correction, sure.

Seidman: When you asked why it's troublesome, I think there are two things that trouble me. First, the kind of self-righteousness that I had when I was younger is dented by the existence of people who are younger now who think that the ideas I had and the things I cared about are just not relevant or not important. That's just a general intellectual problem. But then I don't think that can be separated from a personal reaction. People don't like to feel that time has passed them by. Ultimately, what people really don't like is the realization of approaching death and the extirpation that everything that we cared about and everything that mattered. In the end everything is just going to go away, and as you get older that realization becomes harder and harder to ignore. It's just a problem.

Tushnet: I have a couple of reactions. One is the Wordsworth line about the French Revolution, "Bliss it was in that dawn to be alive but to be young was very heaven." 26 That is how young people are, and Wordsworth was writing in retrospect as I understand it, so yes that kind of passion and clarity is characteristic of young people and in some fundamental way to be admired even if from our advanced age we can see that things are not as clear and all that sort of stuff, but good for them. The other is that there are lot of parts of our lives that don't have anything to do with our professional activities and you know it's probably true that with advancing age those other things might appropriately become more important to us. Just to take the kind of example I gave before. If there is something I write today that is going to be dismissed now but in 20 years will seem reasonable, fundamentally I don't care about

26 William Wordsworth, The French Revolution as it Appeared to Its Enthusiasts at Its Commencement (1815), available at https://en.wikisource.org/wiki/Page:Poems_by_William_Wordsworth_(1815)_ Volume_2.djvu/77. 
that, right, because in 20 years I'm not going to be around, so the kind of thing that I could say about my career earlier I can't say about what I'm doing now.

On the other hand, you know there are the kids and the grandkids and they are going to be around and raising kids was important when you were raising them. Our lives are not always, not fully occupied, by our professional identities. And so now that I've gotten to this point, I think what I want to say is that one's retrospective view of one's professional life and activities, and the view one has as a professional of the next generation, really don't have much to do with one's view of one's life as a whole.

Seidman: I think my ambition going forward is to be a better old codger than the last generation's old codgers, to be more decent, more kind and more insightful. I suppose given where we are that's ambition enough.

And I guess that's a wrap. 